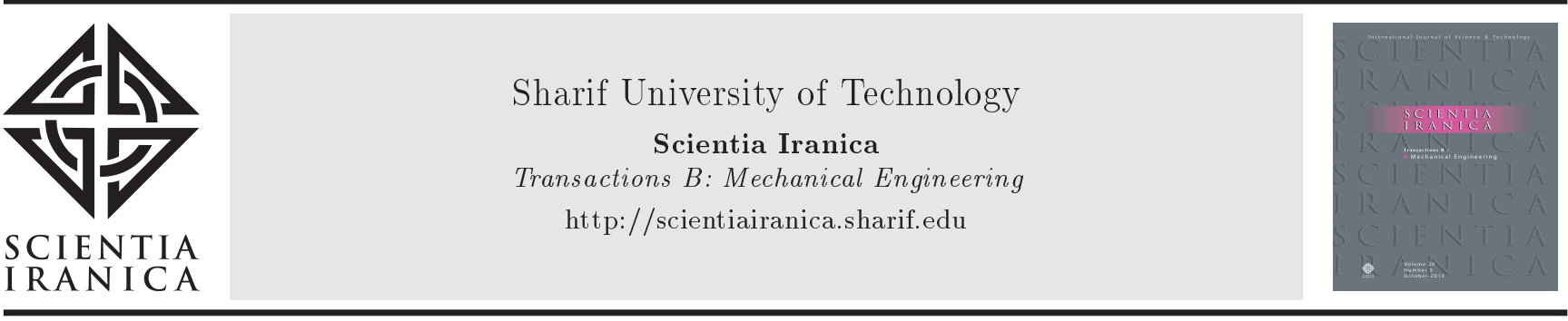

Research Note

\title{
Exergy-economic-environment optimization of the waste-to-energy power plant using Multi-Objective Particle-Swarm Optimization (MOPSO)
}

\author{
F. Esmaeilion, A. Ahmadi*, and R. Dashti \\ Department of Energy Systems Engineering, School of Advanced Technologies, Iran University of Science \& Technology (IUST), \\ Tehran, P.O. Box 16846-13114, Iran.
}

Received 11 March 2020; received in revised form 6 November 2020; accepted 1 February 2021

\author{
KEYWORDS \\ Exergy; \\ MOPSO; \\ Exergoenvironmental; \\ Exergoeconomic; \\ Waste-to-energy.
}

\begin{abstract}
The present study brings together the benefits of the results of exergy, exergoeconomic, and exergoenvironmental analyses as well as optimization of a wasteto-energy power plant. First, exergoeconomic balance for each stream was calculated. To validate the current simulations, the actual data from the Amsterdam waste-to-energy power plant in working conditions were examined. Moreover, the behaviors of the influential parameters in the objective functions were evaluated. In order to perform multi-objective optimization, Multi-Objective Particle-Swarm Optimization (MOPSO) algorithm was employed. To obtain the optimum operating conditions, 14 design parameters and 3 objective functions were taken into consideration, with the total cost rate, total exergy efficiency of the cycle, and environmental impacts as the objective functions. Finally, the TOPSIS decision-making method determined the optimum-operating conditions. The results of exergy analysis indicated that the most exergy destruction belonged to the incinerator unit at $66 \%$. Instead, the pumps contributed the least in this field (approximately 1\%). Under the influence of the optimization process, the total exergy efficiency of the power plant increased from $30.89 \%$ to $38.9 \%$ at the total cost of 5188.05 USD/hour. A comparison of the obtained results from the optimization procedure revealed that introducing optimum working condition would cause an increase in the exergy efficiency and a decrease in the exergy destruction among the components.
\end{abstract}

(C) 2021 Sharif University of Technology. All rights reserved.

\section{Introduction}

Municipal Solid Waste (MSW) has turned into one of the major challenges of human life in the metropolises. In order to reduce the environmental impacts of wastes, a variety of techniques have been proposed among

\footnotetext{
*. Corresponding author. Tel.: +98-21-73225832 E-mail addresses: farbodesmailion@gmail.com (F. Esmaeilion); a_ahmadi@iust.ac.ir (A. Ahmadi); rdashti@iust.ac.ir (R. Dashti)
}

which burial or landfilling is a well-known conventional method. In this method, available energy and usable materials of waste are eliminated. In a Waste-ToEnergy (WTE) unit, after proper separation, MSW is burned and the resulting energy is used to generate power and heat [1]. Since these types of power plants have a very small proportion of electricity production and given the global population growth, the demand for such units is dramatically increasing $[2,3]$. Therefore, given the population growth of the countries and subsequent generation of waste in the metropolitan areas, it is important to examine the factors that affect the performance of these units. One of the 
main challenges in some developed and developing countries with the increasing rate of population growth is collecting, recycling, treating, and disposing of solid wastes and sewages that are increasingly accumulated [4-6]. The basic foundations for sustainable development include management of waste in a cost-effective, energy-efficient, and sustainable way. It should be emphasized that public health, safety, and environmental protections are also affected by waste management $[7,8]$. With the development of technologies in the field of power generation, a new structural design for a wide variety of power plants has been proposed, one of the most important parts of which is WTE sector. This technology is capable of controlling the process of converting waste to energy, providing the available process, and extracting the maximum energy from wastes $[9,10]$. As a result, analysis of these systems is of great significance. The obtained results from various studies referred to exergy and economic analyses as strong tools for assessment of energy systems [11-14]. Exergy is an important criterion for measuring the degree of unbalance between the matter and its surrounding. This criterion contains economic and environmental parameters that express its full functionality. Makkeh et al. [15] carried out the exergy and exergoeconomic optimization of a cogeneration system by Particle Swarm Optimization (PSO) to indicate the most optimum thermodynamic properties in the integrated cycle. According to the obtained results from exergy destruction analysis, the pumps contributed the least in this regard. Ahmadi et al. [16] performed an exergy and economic investigation of an integration of heliostat solar receiver, gas turbine, and air bottom cycle. Gargari et al. [17] conducted an analysis and optimization for a biogas-based multigeneration system to determine the maximum amount of thermal efficiency and exergy efficiency with the minimum values of unit product cost and environmental penalty charge rates.

Alrobaian [18] took benefits of energy, exergy, and economic factors to enhance the productivity of waste incineration CHP plant. In the presented configuration, the thermal efficiency of the steam recovery unit was $95 \%$ and the Waste Incineration Unit (WIU) contributed the most in the exergy destruction term. Fuji et al. [19] optimized the rate of waste utilization to enhance the exergy efficiency of the WTE cycle. The results of the comparison made between MSW and NG (Natural Gas) indicated that using waste in appropriate places would increase the impacts of $\mathrm{CO}_{2}$ emission by more than two times. Multi-criteria optimization of a WTE-TEG (thermoelectric generator) integrated cycle illustrated that the thermodynamic properties (mass flow rate, temperature, etc.) of cooling flow in condenser had a direct effect on the system performance [20]. Carneiro and Gomes [21] investigated the technical operation of WTE plants. Based on the obtained results, the Amsterdam WTE power plant underwent the highest investment costs per annual inputted MSW.

The exergy and energy study of pyrolysis in the rotary kiln revealed that the pyrolysis exergy efficiency of the simulated mixture of plastic ranged from 59 to $66 \%$, while the HHV could vary for different types of products [22]. Yatsunthea and Chaiyat [23] revealed the feasibility of using medical and municipal wastes in comparison with ORC and incinerator. The energy and exergy analyses showed that the relevant efficiencies were calculated as $8.05 \%$ and $39.98 \%$, respectively. In addition, the levelized cost of exergy was estimated to be $0.257 \mathrm{USD} / \mathrm{kWh}$. Chen et al. [24] designed a new waste incineration power plant and evaluated its performance by exergy criterion. Through optimization, the exergy productivity of waste-to-power increased by $7.88 \%$ and the total exergy efficiency grew by $0.43 \%$.

Ehyaei et al. [25] optimized a Parabolic-Trough Collector (PTC) using a multi-objective particle swarm algorithm to achieve optimum conditions in exergy and economic fields. The optimization outcomes revealed that the exergy efficiency and heat cost were calculated as $29.22 \%$ and $0.0142 \mathrm{USD} / \mathrm{kWh}$, respectively. In this study, the Pareto front demonstrated the ideal values of objective functions. Shaygan et al. [26] examined hybrid polymer electrolyte membrane fuel cell and photovoltaic cells to ensure ideal conditions in exergy and economic terms. In the considered system, the highest value for exergy destruction belonged to the PV cell at $37.67 \mathrm{~kW}$ while the lowest value to the compressor at $3.7 \mathrm{~kW}$. An innovative combined power and refrigeration cycle through geothermal energy was presented by Ehyaei et al. [27]. In the mentioned cycle, the evaporator contributed the most to the exergy destruction rates at $1397,1 \mathrm{~kW}$. Further, the optimization procedure improved the energy efficiency of the system by $38 \%$. Exergy analysis of a diesel engine was performed by Nabi et al. [28] who investigated the influential parameters in system performance and their impacts. Ahmadi et al. [29] performed the exergoenvironmental assessment of gas and air bottoming cycles by incorporating heat recovery Steam Generator (SG) to the whole system and the obtained results indicated that the energy efficiency increased up to $67.6 \%$. Shamoushaki et al. [30] optimized a gas turbine power plant and according to the obtained results, the combustion chamber contributed the most to exergy destruction and the performance of the system was considerably improved by multi-objective particle swarm and genetic algorithms (separately). In 2016, an exergy-economic analysis was carried out on a biogasification plant and the cost of exergy for different components of the plant was assessed [31]. Jack and Oko [32] performed an exergoeconomic analysis of the 
Harcourt WTE power plant. Their obtained results indicated that the thermal and exergy efficiencies of the cycle were $36.91 \%$ and $31.36 \%$, respectively. Of note, the highest cost rate of the exergy destruction belongs to the SG and incinerator. However, the incinerator had the highest proportion of irreversibility due to the high temperature. Some studies have investigated similar systems such as conversion of heat to energy using the urban environmental sources [33]; economic and environmental review of the WTE systems for MSW [34]; energy potential of MSW [35]; economic, energy, and environmental analyses for MSW [36]; and assessment of the exergy life cycle of the WTE power plant [37]. In the study of mass burner incinerator, the exergy and energy terms of the WTE power plant in Tehran, Iran have been calculated. The method functions based on the percentage of compounds in the MSW of Tehran [38].

The novelty of the present study lies in its optimization of the WTE power plant through the exergy-economic-environmental approaches. The environmental analysis also makes the results unique. Further and even more importantly, examination of the effective parameters in the WTE plant provides reliable results and a better understanding of the power plant systems. Using PSO in multi-objective optimization is a novel procedure for calculating the optimum conditions of the energy systems that have desirable outcomes, thus affecting system performance and associated productivity. The results of this study are briefly listed in the following:

- The WTE power plant was optimized in order to achieve ideal performance conditions in the exergy, economic, and environmental (3E) terms;

- The environmental performance of the power plant was evaluated through the incinerated MSW. In this field, environmental impacts were considered by their imposed costs;

- The effective parameters in the WTE power plant were examined, and the important parameters were compared with the actual value obtained from the Amsterdam WTE power plant, thus representing the appropriate results in the field of simulation and equation implementation;

- Exergy and economic analyses of the bottom ash were conducted to determine the way of treatment and processing of this part;

- The TOPSIS decision-making method was employed to demonstrate the best and worst conditions for the system. These values are based on the overall exergy efficiency and cost rate;

- Pareto front was drawn to declare the obtained points from the optimization process, and the most ideal point (lowest cost with the highest efficiency) was identified with the help of TOPSIS;

- The performance of the system was evaluated before and after optimization.

\section{Mathematical modeling}

\subsection{Process description}

In this power plant, MSW with air required for combustion enters into the furnace, and the produced heat generates the high-pressure steam. The system involves two main sections: WIU and Rankine cycle for recovering the produced thermal energy.

In the incinerator, Green-House Gases (GHGs) are emitted. Meanwhile, the furnace is designed under high-oxidizable settings, and there is no methane $\left(\mathrm{CH}_{4}\right)$ emission in gases leaving the chimney. Moreover, the effect of bottom ash (state 41) on the exergy efficiency was evaluated and the total cost was calculated in this study. As the final point, fly ash and combustion products flow to the environmental control units. In the incinerator, the roof crane mixes the MSW. In the furnace, temperatures are typically higher than $1000^{\circ} \mathrm{C}$ and no other types of fuel are needed. Sometimes, there is an oil burner system in the furnace that is used to start and stop the furnace operation. After the combustible process, what remains is known as slag (or ash). The bottom ash is dumped and conveyed to be used in recycling. The boiler consists of long welded pipelines. Water is heated by hot emitted exhausts and converted to high-temperature steam. Steam with higher pressure will produce higher power. At the same time, increased pressure and temperature result in a higher risk of equipment corrosion and higher maintenance costs. In this study, we used FDF (Forced Draft Fan) on the entrance side and IDF (Induced Draft Fan) on the exhaust side. In both of them, the chemical composition of the gases is constant and will remain unchanged. Through the FDF and IDF, the temperature increment is around $3^{\circ} \mathrm{C}$ and $7^{\circ} \mathrm{C}$, respectively.

The high-pressure steam is inputted into the steam turbine with the pressure and temperature of 130 bar and $440^{\circ} \mathrm{C}$, respectively. The entire power plant is presented in Figure 1. The gross generation capacity of the power plant is about $100 \mathrm{MW}$, which is reduced to $93 \mathrm{MW}$ by decreasing the power consumed at the pumps and losses. The plant has three separate turbines: High Pressure Turbine (HPT), Intermediate Pressure Turbine (IPT), and Low Pressure Turbine (LPT). The inlet pressures for these steam turbines are 130, 25, and 4 bar, respectively. The main steam expands through the HPT, IPT, and LPT to generate electricity by shaft work. At the next stage, the last exhausted steam is condensed in the one-through water cooling condenser. To improve the thermal effective- 


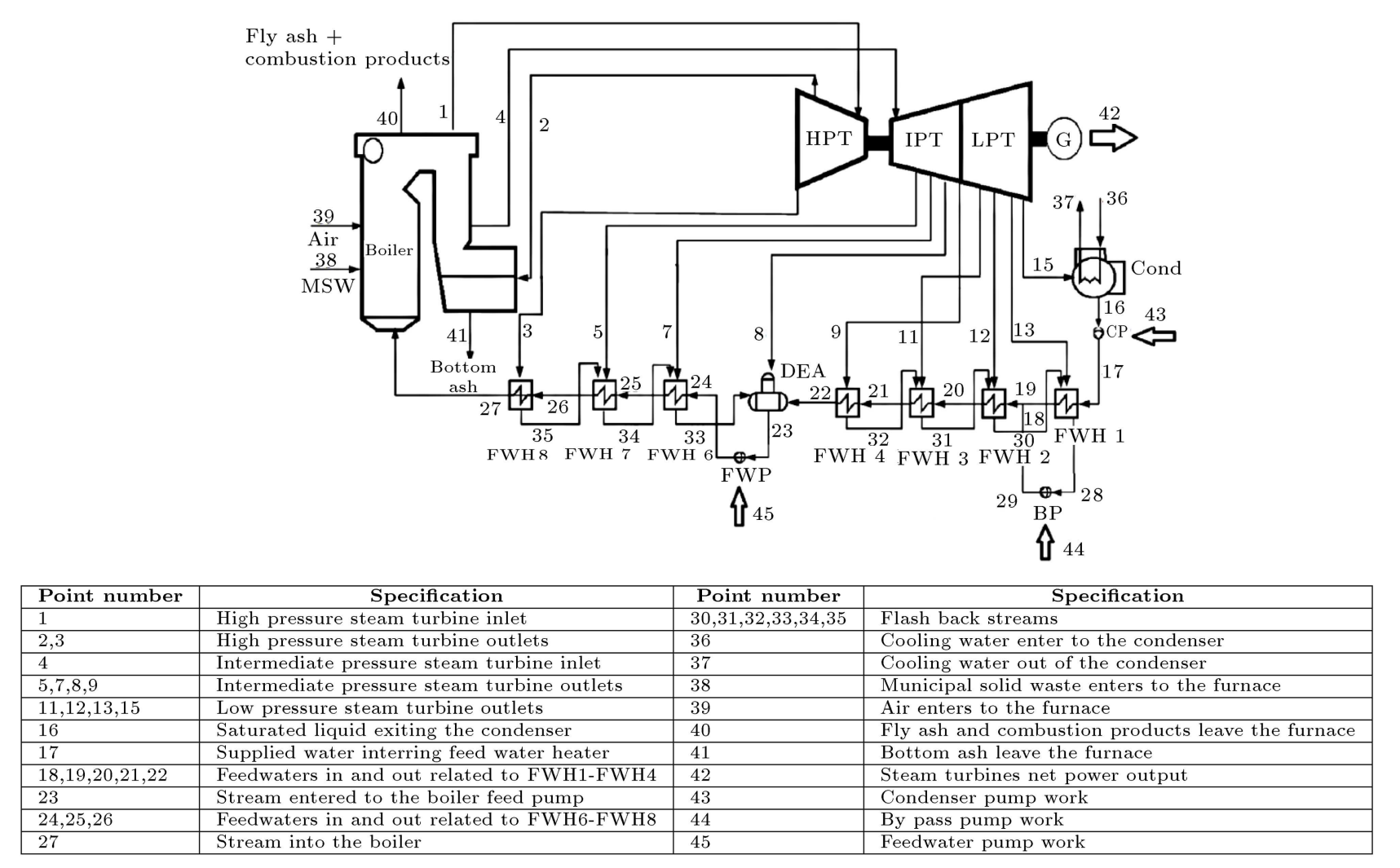

Figure 1. Schematic of waste-to-energy power plant with streams specifications and associated power.

ness, portions of the expanded steam are extracted from different places of the turbine to heat the feedwater in the regeneration sub-systems including four lowpressure units (FWH1-FWH4), a deaerator (DEA), and the remaining three high-pressure components (FWH6-FWH8). Furthermore, one ST and three onstream pumps are embedded to increase the water pressure (CP, BP, and FWP). In this regard, states 43-45 represent the power consumption while state 42 indicates the power production. In this system, the air and stack flue gas temperatures are 298 and $643 \mathrm{~K}$, respectively. Further, the isentropic efficiencies of pumps and turbines are 80 and $85 \%$, respectively.

The cooling fluid in the condenser is water whose temperature increases with one pass from $22^{\circ} \mathrm{C}$ to $48^{\circ} \mathrm{C}$, thus cooling down the working fluid. Demanded solid waste rate based on its Lower Heating Value (LHV) for steam combustion and generation at $440^{\circ} \mathrm{C}$ is $19.07 \mathrm{~kg} / \mathrm{s}$.

\subsection{Energy modeling}

For mathematical modeling of the cycle, several simple assumptions are considered to provide a less complicated analysis by maintaining sufficient accuracy and taking into consideration the following remarks:

1. All processes are steady;

2. Inlet air and combustion products are ideal gas mixtures which have low pressures at high temperatures; hence, the ideal assumption is reasonable;

3. The heat loss intended for the combustion chamber (incinerator) is equal to $2 \%$ of the lower heating value of the fuel and the rest of the components are adiabatic;

4. The pressure drops in the connections are ignored;

5. The thermal loss through the connections and accessories is ignored;

6. The feedstock (MSW) has steady compositions. In the boiler, the excess air is $60 \%$ and the minor heat loss is $2 \%$.

Of note, the furnace gate pressure drop is 0.622 bar. The incinerator is equipped with IDF and FDF. Moreover, the minimum flue gas exit temperature is $137.8^{\circ} \mathrm{C}$ and air temperature at the inlet state is $25^{\circ} \mathrm{C}$. On the contrary, some non-essential parameters such as energy loss due to unburned carbon, calcination of sorbent, sulfation as well as unburned carbon in ash, or plume visibility index are ignored or remain unknown.

The first law of thermodynamics illustrates the original concept of energy conservation. The related equation can be shown as Eq. (1):

$$
E_{\text {in }}-E_{\text {out }}=\Delta E_{\text {system }} .
$$

In this equation, the total energy $(E)$ changes based 
Table 1. Energy equations for WTE (Waste-To-Energy) power plant components based on energy balance.

\begin{tabular}{ll}
\hline \multicolumn{1}{c}{ Equipment } & \multicolumn{1}{c}{ Equations } \\
\hline Pump & $\dot{W}_{\text {Pump }}=\dot{m} \nu\left(P_{2}-P_{1}\right) \& h_{2}=h_{1}+\frac{\dot{W}}{\dot{m}}=h_{1}+\nu\left(P_{2}-P_{1}\right)$ \\
Heat exchanger & $\sum \dot{m}_{i} h_{i}=\sum \dot{m}_{e} h_{e} \& \Delta Q=\dot{m}\left(h_{i}-h_{e}\right) \& h_{i}-h_{e}=\int C_{p} d T$ \\
Combustion chamber & $\dot{m}_{a} h_{a}+\eta_{C C} \dot{m}_{M S W} L H V_{M S W}=\dot{m}_{g} C_{P A}\left(T_{40}-T_{39}\right)+\dot{m}_{\text {ash }} h_{\text {ash }}$ \\
Steam turbine & $\sum \dot{m}_{i} h_{i}=\dot{W}_{\text {steam turbine }}+\sum \dot{m}_{e} h_{e} \& \eta_{\text {steam turbine }}=\frac{\dot{W}_{\text {actual }}}{W_{\text {isentropic }}}$ \\
\hline
\end{tabular}

on the difference between the total input and output of energy through the system. Eqs. (2) and (3) show the energy balance and continuity below:

$$
\begin{aligned}
\sum \dot{m}_{i} & =\sum \dot{m}_{e} \\
\dot{Q}-\dot{W} & =\sum_{e} \dot{m}_{e} h_{e}-\sum_{i} \dot{m}_{i} h_{i} .
\end{aligned}
$$

Based on this section, essential equations for physical and thermal modeling can be provided. Given the energy balance (Figure 1), the related equations for WTE power plant components are presented in Table 1.

In Table $1, \dot{m}$ is the mass flow rate through the pump, $\nu$ the specific volume of the fluid, $\dot{W}$ the associated work, $h$ the specific enthalpy, $C_{P}$ the specific heat at constant pressure, $L H V$ the Lower Heating Value, and $P$ the pressure. Here, $i$ and $e$ represent the input and output states, respectively. Also, the heat loss from the control volume systems is ignored. Moreover, the condenser is a different type of heat exchanger. In the corresponding relations, $\Delta$ represents the changes and $C_{p}$ is the heat transfer coefficient at a constant pressure. In the combustion chamber relations, $a, g$, ash, and $C C$ are the input air, fuel, combustion products (flue gas), bottom ash, and combustion chamber, respectively. In the steam cycle, the energy in the steam is converted into the mechanical energy by the steam turbine. Steam turbine plays an important role in the Rankin cycle. The energy balance for the control volume is observed, where $\dot{W}_{\text {steam turbine }}$ is the steam turbine output work rate. The relation of the isentropic efficiency of a steam turbine is given. Figure 1 illustrates all of the processes and components.

\subsection{Exergy analysis}

Exergy analysis works based on the first and second laws of thermodynamics that combines the principles of energy conservation. The main objective of the exergy analysis is primarily optimization. If properly done, it shows where the largest energy losses occur in the power plant and which part needs improvement in its design. Hence, exergy is often considered an economic value criterion [39-41]. It can also be divided into four parts: physical, chemical, kinetic, and potential parts. In this study, the kinetic and potential parts were neglected in this study.
By applying the first and second laws of thermodynamics, the equilibrium of exergy is given in Eq. (4):

$$
\begin{aligned}
& E \dot{x}_{Q}+\sum \dot{m}_{i} e x_{i}=\sum \dot{m}_{e} e x_{e}+\dot{E} x_{W}+\dot{E} x_{D}, \\
& \dot{E} x_{Q}=\left(1-T_{o} / T_{i}\right) \dot{Q}_{i}, \\
& \dot{E} x_{W}=\dot{W}, \\
& \dot{E} x_{D}=\sum \dot{E} x_{i}-\sum \dot{E} x_{e}=T_{o} \dot{S}_{g e n} .
\end{aligned}
$$

In Eqs. (4)-(7), $T_{0}, T_{i}, \dot{W}, \dot{Q}$, and $\dot{S}_{g e n}$ are the ambient temperature, inlet temperature, rate of associated work, rate of inlet heat, and rate of entropy generation, respectively. Specific exergy can be calculated through Eq. (8):

$$
e x=e x_{p h}+e x_{c h} .
$$

In the above equation, subscripts $p h$ and $c h$ denote the physical and chemical exergy, respectively. Physical exergy of a system is defined as the maximum useful theoretical work in a process in which the system finds balance with an environment. Chemical exergy points to the distinction between the chemical composition of a system and the reference environment $[42,43]$.

$$
e x_{p h}=\left(h-h_{o}\right)-T_{o}\left(s-s_{o}\right),
$$

where $h$ and $s$ are enthalpy and entropy, respectively, and $T_{o}$ is the ambient temperature.

$$
e x_{\mathrm{mix}}^{c h}=\left[\sum x_{i} e x_{i}^{c h}+R T_{o} \sum x_{i} \ln x_{i}\right] \text {. }
$$

The chemical exergy for the gas mixture is expressed in Eq. (10), where $x$ is the molar ratio, $R$ the gas constant, $T_{o}$ the ambient temperature, and $e x^{c h}$ the molar standard chemical exergy [44]. While evaluating the chemical exergy, the systemic particles should refer to the properties of a suitable collection of environmental materials. However, for waste, the method for calculating the chemical exergy differs from hydrocarbons through Eq. (12) $[45,46]$ :

$$
\begin{aligned}
\dot{E} x_{\text {waste }}= & \dot{m}_{\text {waste }} e x_{\text {waste }}, \\
e x_{\text {waste }}= & 1812.5+295.606 \mathrm{C}+587.354 \mathrm{H}+17.506 \mathrm{O} \\
& +17.735 \mathrm{~N}+95.615 S-31.8 \mathrm{~A},
\end{aligned}
$$

where $\mathrm{C}, \mathrm{H}, \mathrm{O}, \mathrm{N}, \mathrm{S}$, and A are the molar percentages of 
carbon, hydrogen, oxygen, nitrogen, sulfur, and ash in the waste, respectively. The LHV of the MSW can be calculated using Dolang equation to approximate to the thermal value, as shown in Eq. (13) [46]. The entropy of solid waste can be calculated through Eq. (14) [45]. HHV can be calculated based on Eq. (15) [47]. Here, $\mathrm{C}, \mathrm{H}, \mathrm{O}, \mathrm{N}, \mathrm{S}, \mathrm{H}_{2} \mathrm{O}$ are the weight percentages of the waste elements.

$$
\begin{aligned}
& L H V_{\text {waste }}=337 \mathrm{C}+1428\left(\mathrm{H}-\frac{\mathrm{O}}{8}-\frac{\mathrm{Cl}}{35.5}\right)+9, \\
& S^{o}=0.0055 \mathrm{C}+0.0954 \mathrm{H}+0.0096 \mathrm{O}+0.0098 \mathrm{~N} \\
& +0.0138 \mathrm{~S}\left(\mathrm{~kJ} . \mathrm{kg}^{-1} \cdot \mathrm{K}^{-1}\right), \\
& H H V=\left(1-\frac{\mathrm{H}_{2} \mathrm{O}}{100}\right)(-0.3578 \mathrm{C}-1.1357 \mathrm{H} \\
& +0.0845 \mathrm{O}-0.0594 \mathrm{~N}-0.1119 \mathrm{~S}) .
\end{aligned}
$$

According to the obtained results in 2008, if the composition between the elements is known, the amount of exergy can be calculated for fuels mixed with various compounds [48]. In this respect, $\beta$ is a constant property (quality factor or exergy coefficient) calculated based on Eqs. (16) and (17) using the provided data:

$$
\begin{aligned}
\beta_{L H V}= & \frac{E \dot{x}_{C h}}{L H V}, \\
\beta_{L H V}= & {\left[1.0412+0.216\left(\frac{\mathrm{H}_{2}}{\mathrm{C}}\right)\right.} \\
& -0.2499\left(\frac{\mathrm{O}_{2}}{\mathrm{C}}\right)\left[1+0.7884\left(\frac{\mathrm{H}_{2}}{\mathrm{C}}\right)\right] \\
& \left.+0.045\left(\frac{\mathrm{N}_{2}}{\mathrm{C}}\right) /\left[10.3035\left(\frac{\mathrm{O}_{2}}{\mathrm{C}}\right)\right]\right] .
\end{aligned}
$$

The chemical exergy associated with the bottom ash is directly related to its temperature coming from the furnace. In all cases, the temperature of the bottom ash is equal to that of the combustion products. Eq. (17) provides a proper insight into the exergy content of the MSW and validates Eq. (18):

$$
\begin{aligned}
& e x_{\mathrm{ash}}=0.0004056 T_{\mathrm{ash}}^{2}+0.01057 T_{\mathrm{ash}}-54.44, \\
& e x_{\mathrm{ash}}=0.01 A . n_{\mathrm{ash}}\left(\sum x_{i} e x_{i}^{0}+R T_{o} \sum x_{i} \ln x_{i}\right) .
\end{aligned}
$$

In Eq. (19), $R$ is the constant of the gases, $A$ the mass element percentage in ash, $n$ the number of oxides in the ash, $x_{i}$ the molar ratio, and $e x_{i}$ the standard chemical exergy of the components in the ash. In the exergy analysis, the exergy of steam is calculated at each point. The major share in the irreversibility and exergy destructions for boilers and turbines is associated with the chemical reaction and thermal losses in the flow paths; however, in the water heaters and the condenser, the high temperature difference between the cold and hot water is an effective factor. Through the first law of thermodynamics, energy conservation can be defined. The associated energy equations for each component are used for suitable identification for all streams. The equations for exergy flow, exergy destruction, and exergy efficiency associated with each component are given in Table 2 .

\subsection{Economic analysis}

In conventional economic analysis, the cost balance for a general system that works in a steady state is usually provided by Eq. (20) [43]:

$$
\dot{C}_{P, \text { tot }}=\dot{C}_{F, \text { tot }}+\dot{Z}_{\text {tot }}^{C I}+\dot{Z}_{\text {tot }}^{O M},
$$

where, $\dot{C}_{P}, \dot{C}_{F}, \dot{Z}^{C I}$, and $\dot{Z}^{O M}$ are the production cost, fuel cost, investment cost, and operation and maintenance cost rates, respectively. According to the cost balance, the cost of the system production $\left(\dot{C}_{P}\right)$ equals the total cost of production costs, i.e., the fuel cost rate $\left(\dot{C}_{F}\right)$, investment costs $\left(\dot{Z}^{C I}\right)$, and operation and maintenance costs $\left(\dot{Z}^{O M}\right)$. Here, $\dot{C}$ represents the cost rate associated with the flow of exergy, material flow, work, or heat transfer and $\dot{Z}$ represents the rest of the costs. Accordingly, for a component receiving heat and power, it can be defined as Eq. (21) [43]:

$$
\sum\left(c_{e} \dot{E}_{e}\right)_{k}+c_{w, k} \dot{W}_{k}=c_{q, k} \dot{E}_{q, k}+\sum\left(c_{i} \dot{E}_{i}\right)_{k}+\dot{Z}_{k},
$$

where, $\dot{E}_{i}, \dot{E}_{e}, \dot{E}_{q}$, and $\dot{W}$ are the input exergy rate, output exergy rate, rate of exergy transfer through heat and power consumption, or production in the system, respectively. In addition, $c$ is the cost per exergy in these exergoeconomic equations. The investment cost rate can be obtained through Eq. (22):

$$
\dot{Z}_{K}=\frac{P E C_{k} \cdot \Phi \cdot C R F}{N \cdot 3600} .
$$

In the defined equation for $\dot{Z}_{K}, \Phi$ is the maintenance factor equal to $1.06, \mathrm{CRF}$ is the recovery factor of capital expressed by the annual interest rate $(i)$, and $n$ is the period for the annual payback for calculated capital illustrated by the operating hours of the plant per year. Table 3 represents the values of PEC for various components.

$$
C R F=\frac{i \cdot(1+i)^{n}}{(1+i)^{n}-1}
$$

All of the presented equipment costs in this economic analysis must be updated to the same reference year, 
Table 2. Exergy flow, exergy destruction, and exergy efficiency equations for the components of WTE (Waste-To-Energy) plant.

\begin{tabular}{|c|c|c|c|c|}
\hline \multicolumn{2}{|c|}{ Component } & \multirow{2}{*}{$\begin{array}{l}\text { Exergy flow equation } \\
\dot{E}_{1}=\dot{E}_{2}+\dot{E}_{3}+\dot{W}_{H P T}+T_{0} \dot{S}_{g e n} \\
\dot{E}_{4}=\dot{E}_{5}+\dot{E}_{7}+\dot{E}_{8}+\dot{E}_{9}+\dot{W}_{I P T}+T_{0} \dot{S}_{g e n} \\
\dot{E}_{10}=\dot{E}_{11}+\dot{E}_{12}+\dot{E}_{13}+\dot{E}_{15}+\dot{W}_{L P T}+T_{0} \dot{S}_{g e n}\end{array}$} & \multirow{3}{*}{$\begin{array}{c}\text { Exergy destruction } \\
\dot{E}_{D, S T}=\sum_{i, S T} \dot{E}-\sum_{e, S T} \dot{E}-\dot{W}_{S T}\end{array}$} & \multirow{3}{*}{$\begin{array}{l}\text { Exergy efficiency } \\
\eta_{e, S T}=\frac{\dot{W}_{S T}}{\left(\dot{E}_{i, S T}-E_{e, S T}\right)}\end{array}$} \\
\hline Turbines & $\begin{array}{l}\text { HPT } \\
\text { IPT } \\
\text { LPT }\end{array}$ & & & \\
\hline \multirow[b]{2}{*}{ Pumps } & $\mathrm{CP}$ & $\dot{E}_{16}+\dot{W}_{C P}=\dot{E}_{17}+T_{0} \dot{S}_{g e n}$ & & \\
\hline & $\begin{array}{c}\text { BP } \\
\text { FWP } \\
\text { FWH1 }\end{array}$ & $\begin{array}{l}\dot{E}_{28}+\dot{W}_{B P}=\dot{E}_{29}+T_{0} \dot{S}_{g e n} \\
\dot{E}_{23}+\dot{W}_{F W P}=\dot{E}_{24}+T_{0} \dot{S}_{g e n} \\
\dot{E}_{17}+\dot{E}_{13}+\dot{E}_{30}=\dot{E}_{28}+\dot{E}_{18}+T_{0} \dot{S}_{g e n}\end{array}$ & $\dot{E}_{D, P}=\dot{W}_{P}+\sum_{i, P} \dot{E}-\sum_{e, P} \dot{E}$ & $\eta_{e, P}=\frac{\left(\dot{E}_{e, P}-E_{i, P}\right)}{W_{P}}$ \\
\hline $\begin{array}{l}\text { Feedwater } \\
\text { heaters }\end{array}$ & $\begin{array}{l}\text { FWH2 } \\
\text { FWH3 } \\
\text { FWH4 } \\
\text { FWH6 } \\
\text { FWH7 } \\
\text { FWH8 }\end{array}$ & $\begin{array}{l}\dot{E}_{19}+\dot{E}_{12}+\dot{E}_{31}=\dot{E}_{30}+\dot{E}_{20}+T_{0} \dot{S}_{g e n} \\
\dot{E}_{20}+\dot{E}_{11}+\dot{E}_{32}=\dot{E}_{31}+\dot{E}_{21}+T_{0} \dot{S}_{g e n} \\
\dot{E}_{21}+\dot{E}_{9}=\dot{E}_{32}+\dot{E}_{22}+T_{0} \dot{S}_{g e n} \\
\dot{E}_{7}+\dot{E}_{24}+\dot{E}_{34}=\dot{E}_{33}+\dot{E}_{25}+T_{0} \dot{S}_{g e n} \\
\dot{E}_{25}+\dot{E}_{5}+\dot{E}_{35}=\dot{E}_{34}+\dot{E}_{26}+T_{0} \dot{S}_{g e n} \\
\dot{E}_{26}+\dot{E}_{3}=\dot{E}_{35}+\dot{E}_{27}+T_{0} \dot{S}_{g e n}\end{array}$ & $\dot{E}_{D, F W H}=\sum_{i, F W H} \dot{E}-\sum_{e, F W H} \dot{E}$ & $\eta_{e, F W H}=\frac{\sum_{e, F W H} \dot{E}}{\sum_{i, F W H^{\dot{E}}}}$ \\
\hline \multicolumn{2}{|c|}{ Condenser } & $\dot{E}_{36}+\dot{E}_{15}=\dot{E}_{37}+\dot{E}_{16}+T_{0} \dot{S}_{g e n}$ & $\dot{E}_{D, \text { Cond }}=\sum_{i, \text { Cond }} \dot{E}-\sum_{e, \text { Cond }} \dot{E}$ & $\eta_{e, \text { Cond }}=\frac{\sum_{e, \text { Cond }} E}{\sum_{i, \text { Cond }} E}$ \\
\hline \multicolumn{2}{|c|}{ Deaerator } & $\dot{E}_{22}+\dot{E}_{8}+\dot{E}_{33}=\dot{E}_{23}+T_{0} \dot{S}_{g e n}$ & $\dot{E}_{D, F W H}=\sum_{i, F W H} \dot{E}-\sum_{e, F W H} \dot{E}$ & $\eta_{e, D e a}=\frac{\sum_{e, D e a} \bar{E}}{\sum_{i, D_{e a}} \dot{E}}$ \\
\hline
\end{tabular}

Table 3. Equipment cost function in the form of the corresponding thermodynamic parameters [32,51].

\begin{tabular}{ll}
\hline \multicolumn{1}{c}{ Component } & Capital or investment cost functions \\
\hline Steam Turbine & $P E C_{S T}=C_{51} \cdot\left(\dot{W}_{S T}^{0.7}\right) \cdot\left(1+\left(\frac{0.05}{1-\eta_{S T}}\right)^{3}\right) \cdot\left(1+\exp \left(\frac{T_{\mathrm{in}-866}}{10.42}\right)\right)$ \\
& $\& C_{51}=3880.5\left(\mathrm{USD} \cdot \mathrm{kW}^{-0.7}\right)$ \\
Condenser & $P E C_{C o n d}=C_{5} \dot{m}_{\text {steam }} \& C_{5}=1,773 \mathrm{USD} \cdot \mathrm{kg}^{-1} \mathrm{~S}$ \\
FeedWater Heater & $P E C_{F W H}=6.6 \times \dot{Q}\left(\frac{1}{\left(\Delta T_{u t}+4\right)}\right)^{0.1} \times \Delta P_{f w}^{-0.08} \times \Delta P_{s}^{-0.04}$ \\
Pump & $P E C_{F W H}=C_{6} \dot{W}_{P}^{0.7}\left(1+\frac{2}{1-\eta_{P}}\right) \& C_{6}=705.48\left(\mathrm{USD}^{-\mathrm{kW}^{0.7}}\right)^{-1}$ \\
Waste Incineration Unit & $P E C_{W I U}=275.8 \dot{m}_{m s w . a}+18,231,500$ \\
Deaerator & $P E C_{D e a}=C_{8}\left(\dot{m}_{\text {water }}\right)^{0.7} \& C_{8}=74,788\left(\frac{\mathrm{USD}}{\mathrm{kWW}^{0.7}}\right)$
\end{tabular}

i.e., the year used as a basis for the cost studies. At different times, this procedure is carried out using an appropriate Cost Index (CI) [49]. Eq. (24) is shown in Box I. In this case, the index factor and index value for
2018 are 1.00 and 1638.2 , respectively; for 1995 , they are 1.61 and 1020.4, respectively [50].

To calculate the cost of equipment (Table 3) employed for the WIU, $\dot{m}_{m s w . a}$ is used as the annual

Cost in the reference year $=$ Original $\operatorname{cost} \times\left(\frac{\operatorname{cost} \text { index for the reference year }}{\operatorname{cost} \text { index for the year when the original cost was obtained }}\right)$. 
waste incineration rate (tone/year). In the feedwater heater, $\dot{Q}$ is the heat transfer rate in the feedwater heater, $\Delta T_{u t}$ is the difference between the temperatures of the terminals, and $\Delta P_{f w}$ and $\Delta P_{s}$ are the pressure drops in the feedwater and steam, respectively. WIU emissions have negative impacts on the environment. In this regard, the main objective is to reduce the environmental impacts upon increasing the efficiency of energy conversion processes and, consequently, reducing fuel consumption. In recent years, particular attention has been given to carbon dioxide emissions as the most important greenhouse gas. However, other emissions ( $\mathrm{CO}$ and $\mathrm{NO}_{x}$ ) have been also taken into consideration. The available volumes of fuel in grams per kilogram is prevented from entering the furnace stack [10]. Such emissions from WTE power plants are estimated through net electricity production ( $\mathrm{kWh}$ ) or climate coefficients considered for each country. Given that the climate coefficients are less accurate and are not defined for $\mathrm{NO}_{x}$ and $\mathrm{CO}$ compounds, calculations are made mainly based on the net power production of the power plant [51].

Data of greenhouse gas emissions $(\mathrm{mg} / \mathrm{kWh})$ point to the total electricity produced by all conventional power plants. Based on a combination of power plants including fossil fuel power plants, nuclear power plants, and renewable energy plants, greenhouse gas emissions from the power plant in a specific climate are considered in creating a global estimation of the emissions in that country. To perform analyses at a local level, instead of considering a power plant, the researchers combine certain factors used in calculations to determine the amount of the required energy to replace the amount of energy produced in the incineration of waste. In Table 4, the emission factors associated with the WTE power plant are introduced [52].

$$
\dot{m}_{i}=\mu_{i} \cdot A E P,
$$

where $\mu_{i}$ is the pollutant emission factor and $A E P$ is the electricity produced. The cost of emission is calculated using Eq. (26):

$$
C_{e n v}=\dot{m}_{\mathrm{CO}} \cdot c_{\mathrm{CO}}+\dot{m}_{\mathrm{NO}_{x}} \cdot c_{\mathrm{NO}_{x}}+\dot{m}_{\mathrm{CO}_{2}} \cdot c_{\mathrm{CO}_{2}} \cdot
$$

The values of $c_{\mathrm{CO}}, c_{\mathrm{NO}_{x}}$, and $c_{\mathrm{CO}_{2}}$ indicate the costs of emissions containing contaminants per kilo-

Table 4. Emission factors for waste to energy power plants based on mg of emission per energy produced (kWh).

Emission Emission factor $\left(\frac{\mathrm{mg}}{\mathrm{kWh}}\right)$

\begin{tabular}{cc}
\hline $\mathrm{CO}_{2}$ & 690000 \\
$\mathrm{CO}$ & 235 \\
$\mathrm{NO}_{x}$ & 660 \\
\hline
\end{tabular}

gram which are $0.02086 \mathrm{USD} / \mathrm{kg}, 6.853 \mathrm{USD} / \mathrm{kg}$, and $0.024 \mathrm{USD} / \mathrm{kg}$, respectively [53].

\section{Optimization}

In this section, multi-objective optimization is performed to optimize the WTE cycle. By identifying the decision variables, simulation codes are developed based on PSO. The PSO algorithm is an imitation of social behaviors. Here, the word "particle" refers to, for example, a bee in a colony or a bird in a flock. Each particle behaves in a distributed path using individual personal information or a collection of particle information. To be specific, if a particle has a suitable route to access food, the rest of the particles use the collective knowledge to follow the intended purpose, even if they are far from the target. Particle knowledge optimization methods are behaviorally inspired algorithms [54]. To implement the optimization procedure, all particles move at a certain velocity to the optimum point; hence, the particle velocities must be determined. To begin with, in the first iteration $(i=$ 1 ), the velocity of all particles is assumed to be zero. In the $i$ th iteration, the two important parameters used by common particles are coordination and velocity:

1. The best value of $x_{j}(i)$ (the coordinates of the $j$ th particle in the $i$ th iteration) is $P_{b e s t, j}$, with the highest value of the objective function, $f\left[x_{j}(i)\right]$, found in the face of the particle $j$ in the previous iteration. The best value for $x_{j}(i)$ is $G_{b e s t}$, with the highest value of the objective function $f\left[x_{j}(i)\right]$, which encounters all previous replays with each of $N$ particles.

2. Finding the velocity of the $j$ th particle in the $i$ th iteration:

$$
\begin{aligned}
& v_{j}(i)= v_{j}(i-1)+c_{1} r_{1}\left[P_{\text {best }, j}-x_{j}(i-1)\right] \\
&+c_{2} r_{2}\left[G_{\text {best }}-x_{j}(i-1)\right] \\
& j=1,2, \cdots, N
\end{aligned}
$$

where $c_{1}$ and $c_{2}$ are individual and social learning rates; $r_{1}$ and $r_{2}$ are randomly distributed numbers from 0 to $1 ; c_{1}$ and $c_{2}$ represent the significance of the memory (position) of particles that are usually assumed to be 2 .

3. The location or coordinates of the $j$ th particle are found in the $i$ th iteration:

$$
x_{j}(i)=x_{j}(i-1)+v_{j}(i) ; \quad j=1,2, \cdots, N .
$$

Ultimately, the convergence analysis of the solution is done at this stage. In case all particles converge to the known values, the method is regarded as convergent. If the convergence is not satisfying, in the previous step, the iteration is $i=i+1$ and the calculation 


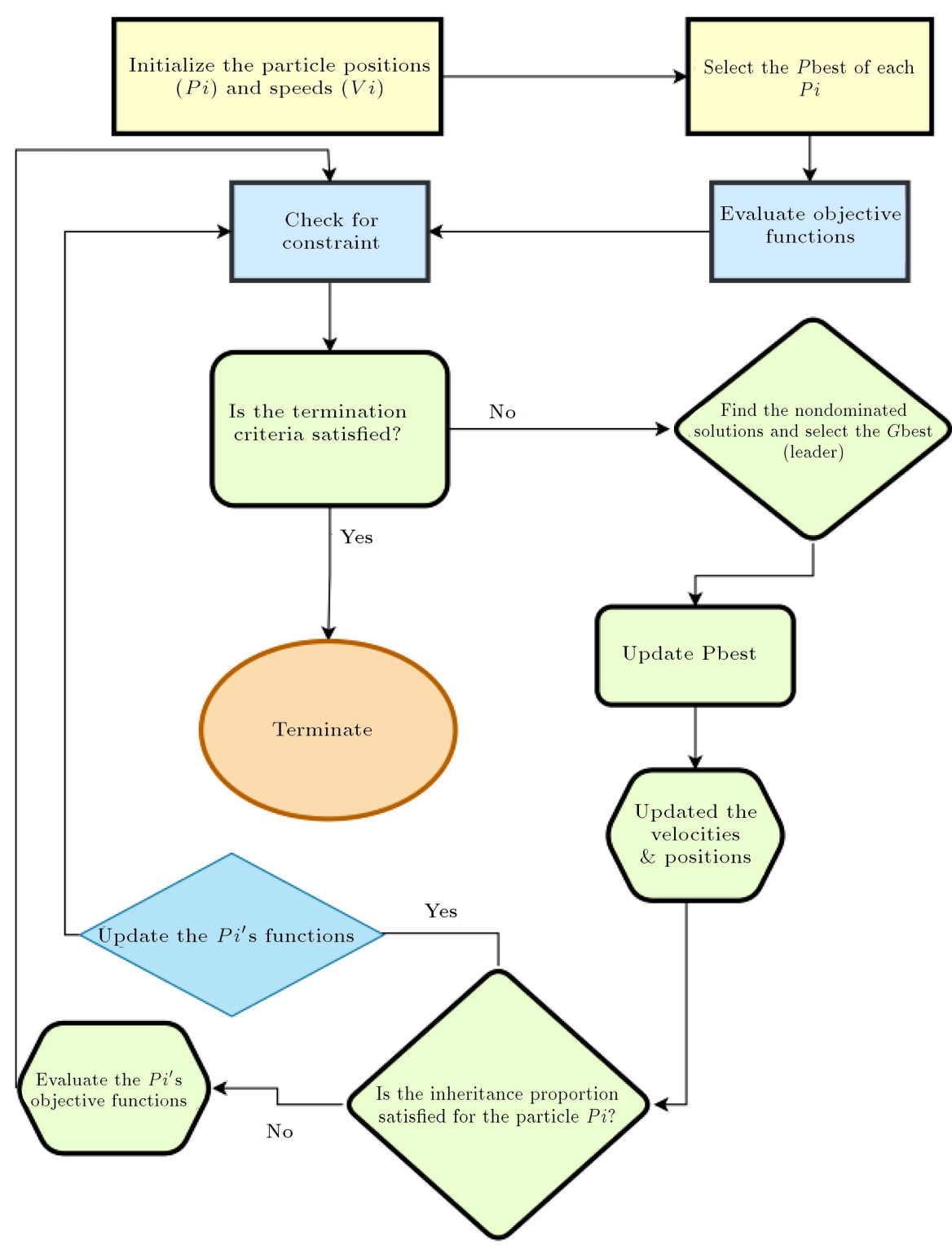

Figure 2. MOPSO (Multiple-Objective Particle Swarm Optimization) flowchart.

of the values of new $P_{\text {best }, j}$ and new $G_{\text {best }}$ continues the iteration process until convergence to the optimum value. Figure 2 indicates the Multi-Objective ParticleSwarm Optimization (MOPSO) flowchart.

In terms of optimization, two main objective functions are defined: while the first objective function is the total exergy efficiency of the cycle, the latter is the objective function of a set of costs such as the costs of fuel, exergy destruction, equipment, and environment. Eqs. (29) and (30) elaborate the abovementioned remarks:

$$
\begin{aligned}
& O F_{1}=\eta_{e x, c y c}=\frac{\dot{W}_{\text {net }}}{\dot{E} x_{M S W}} \\
& O F_{2}=\dot{C}_{\text {fuel }}+\sum \dot{Z}+\sum \dot{C}_{D, i}+\dot{C}_{e n v}
\end{aligned}
$$

$$
\dot{C}_{\text {fuel }}=c_{m s w} \cdot \dot{m}_{m s w} \cdot L H V_{m s w} .
$$

The objective of multi-objective optimization is to maximize the first objective function and minimize the second objective function. Obviously, there is more than one point in the Pareto curve. Optimization requires determination of the decision variables within certain intervals. To this end, 14 decision variables were employed to perform optimization, as shown in Table 5 .

In this study, MATLAB ${ }^{\circledR}$ and EES $^{\circledR}$ software products were used to determine the finest response for the system. Thermodynamic parameters including enthalpy, entropy, exergy, efficiency, etc. were calculated and simulated using $\operatorname{EES}^{\circledR}$ software, and performance assessment of the system and optimization process 
Table 5. Decision variables and their ranges.

\begin{tabular}{cc}
\hline Decision variable & Range \\
\hline$P_{1}($ bar $)$ & $100-170$ \\
$T_{1}(\mathrm{~K})$ & $720-770$ \\
$P_{2}($ bar $)$ & $20-40$ \\
$P_{7}($ bar $)$ & $10-20$ \\
$P_{5}($ bar $)$ & $15-25$ \\
$P_{8}($ bar $)$ & $6-10$ \\
$P_{9}($ bar $)$ & $4-6$ \\
$P_{11}($ bar $)$ & $3-4$ \\
$P_{12}($ bar $)$ & $2-4$ \\
$P_{13}($ bar $)$ & $1.1-2$ \\
$P_{14}($ bar $)$ & $0.05-0.5$ \\
$\eta_{\text {turbine }}(\%)$ & $75-90$ \\
$\eta_{\text {pump }}(\%)$ & $75-90$ \\
$\dot{m}_{m s w}(\mathrm{~kg} / \mathrm{s})$ & $15-25$ \\
\hline
\end{tabular}

(MOPSO) were performed by MATLAB ${ }^{\circledR}$ software. Further, Aspen HYSYS ${ }^{\circledR}$ was employed to simulate the incineration process in the waste incinerator unit, and thermo flow steam master software ${ }^{\circledR}$ was used to simulate the steam cycle as well as the rest of the power plant.

\section{Results and discussion}

To validate these equations, experimental values of the Amsterdam-Netherlands power plant were compared with the simulated values $[55,56]$. In these references, with the help of the collected values of Amsterdam WTE power plant, some of the effective parameters in the system performance analysis were identified.

Table 6 introduces some of the important parameters in the fields of simulation and real values. WTE cycle energy and exergy efficiencies, output power, steam turbine inlet temperature, waste mass flow rate into the furnace, and flue gas temperature at the boiler exit are the values considered in this study that examined the extent of reliability of the thermodynamics modeling and simulation. The percentage error of each parameter is indicative of high accuracy in implementing the main equations. These percentage errors have a small difference and none of them would exceed more than $4 \%$.

Of note, there are influential parameters in the power cycle that affect the operating conditions and cause the changes in the cycle, as shown in Table 7. In addition, this table shows the thermodynamic properties of each point. Table 8 provides the main information of the power plant including the mass flow rate of MSW, mass flow rate of steam at the entrance of HPT, temperature of steam at the entrance of HPT, electrical power, flue gas temperature, and isentropic efficiencies of pumps and turbines.

Clearly, by applying the working fluid into the components, some of its exergy would be destroyed. Determination of the extent of exergy destruction shares facilitates finding the related proportion for each one. Figure 3 presents the percentage of exergy destruction in each of the available components. In this figure, the incinerator unit contributes the most accounting for $66 \%$, while the least proportion belonged to pumps at $1 \%$. In the meantime, other components have almost equal shares in this field.

Upon increasing the inputted waste flow rate to the incinerator, the final cost rate would subsequently increase. However, if the lateral parameters remain constant, the exergy efficiency of the cycle would significantly decrease. Figure 4 indicates the results that have a negative effect on the cycle. Obviously,

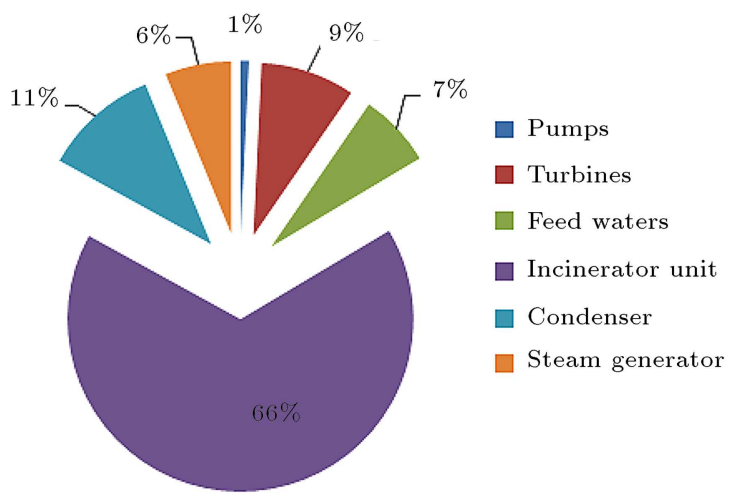

Figure 3. Exergy destruction shares for each component involved.

Table 6. Comparison between the simulated and real values.

\begin{tabular}{lccc}
\hline \multicolumn{1}{c}{ The desired ones } & Simulated value & Real value & Percentage error (\%) \\
\hline Power plant efficiency (\%) & 34.42 & 34.5 & 0.23 \\
Output (MW) & 91.75 & 93.3 & 1.6 \\
Exergy efficiency (\%) & 30.89 & 31.5 & 1.9 \\
Steam temperature (K) & 713 & 693 & 2.8 \\
Waste mass flow rate into the furnace (kg/s) & 19.07 & 18.67 & 2.1 \\
Flue gas temperature at the boiler exit (K) & 471 & 453 & 3.8 \\
\hline
\end{tabular}


Table 7. Streams properties for each point of the considered waste-to-energy power plant.

\begin{tabular}{|c|c|c|c|c|c|c|c|c|}
\hline $\begin{array}{l}\text { State } \\
\text { no. }\end{array}$ & Working fluid & $\begin{array}{c}\text { Temperature } \\
\text { (K) }\end{array}$ & $\begin{array}{l}\text { Pressure } \\
\text { (bar) }\end{array}$ & $\begin{array}{c}\text { Flow } \\
\text { rate } \\
(\mathrm{kg} / \mathrm{s})\end{array}$ & $\begin{array}{c}\text { Entropy } \\
(\mathbf{k J} / \mathbf{k g . K})\end{array}$ & $\begin{array}{l}\text { Enthalpy } \\
(\mathrm{kJ} / \mathrm{kg})\end{array}$ & $\begin{array}{c}\text { Physical } \\
\text { exergy } \\
(\mathrm{MW})\end{array}$ & $\begin{array}{c}\text { Chemical } \\
\text { exergy } \\
(\mathrm{MW})\end{array}$ \\
\hline 1 & Steam & 713.00 & 130.00 & 90.20 & 6.20 & 3164.0 & 118.78 & 43.24 \\
\hline 2 & Steam & 513.50 & 26.50 & 90.20 & 6.32 & 2843.4 & 85.59 & 42.29 \\
\hline 3 & Steam & 513.50 & 26.50 & 1.98 & 6.32 & 2843.4 & 1.92 & 0.95 \\
\hline 4 & Steam & 713.00 & 25.00 & 88.22 & 7.14 & 3329.0 & 106.22 & 42.29 \\
\hline 5 & Steam & 688.20 & 20.83 & 3.38 & 7.16 & 3280.0 & 3.88 & 1.62 \\
\hline 6 & Steam & 606.10 & 133.90 & 0.23 & 3.59 & 1547.4 & 0.11 & 0.11 \\
\hline 7 & Steam & 633.80 & 13.66 & 3.88 & 7.19 & 3174.0 & 4.00 & 1.86 \\
\hline 8 & Steam & 563.80 & 7.52 & 3.76 & 7.23 & 3039.0 & 3.31 & 1.80 \\
\hline 9 & Steam & 497.40 & 4.00 & 0.92 & 7.27 & 2911.2 & 0.68 & 0.44 \\
\hline 10 & Steam & 497.40 & 4.00 & 76.29 & 7.27 & 2911.2 & 56.73 & 36.57 \\
\hline 11 & Steam & 479.40 & 3.33 & 1.40 & 7.29 & 2876.9 & 0.99 & 0.67 \\
\hline 12 & Steam & 451.60 & 2.48 & 1.90 & 7.31 & 2824.0 & 1.23 & 0.91 \\
\hline 13 & Steam & 411.70 & 1.57 & 7.15 & 7.34 & 2748.6 & 4.03 & 3.43 \\
\hline 14 & Steam & 311.74 & 0.13 & 65.85 & 0.55 & 2349.1 & 1.75 & 31.57 \\
\hline 15 & Steam & 324.00 & 0.13 & 66.08 & 0.55 & 2341.3 & 1.56 & 31.68 \\
\hline 16 & Water & 323.90 & 0.43 & 66.08 & 0.72 & 213.4 & 0.30 & 0.17 \\
\hline 17 & Water & 324.16 & 12.69 & 66.08 & 0.72 & 215.2 & 0.38 & 0.17 \\
\hline 18 & Water & 383.00 & 12.13 & 66.08 & 1.42 & 462.0 & 2.93 & 0.17 \\
\hline 19 & Water & 383.40 & 12.13 & 77.44 & 1.42 & 463.9 & 3.45 & 0.19 \\
\hline 20 & Water & 397.40 & 11.15 & 77.44 & 1.57 & 523.0 & 4.53 & 0.19 \\
\hline 21 & Water & 407.40 & 10.26 & 77.44 & 1.68 & 565.5 & 5.38 & 0.19 \\
\hline 22 & Water & 413.80 & 9.77 & 77.44 & 1.75 & 593.1 & 5.96 & 0.19 \\
\hline 23 & Water & 440.90 & 7.52 & 90.43 & 2.02 & 709.8 & 10.12 & 0.23 \\
\hline 24 & Water & 443.00 & 136.00 & 90.43 & 2.03 & 726.4 & 11.51 & 0.23 \\
\hline 25 & Water & 468.50 & 135.40 & 90.43 & 2.27 & 837.5 & 14.97 & 0.23 \\
\hline 26 & Water & 489.30 & 134.80 & 90.43 & 2.46 & 930.1 & 18.13 & 0.23 \\
\hline 27 & Water & 498.40 & 134.50 & 90.43 & 2.55 & 971.5 & 19.62 & 0.23 \\
\hline 28 & Water & 385.80 & 1.57 & 11.36 & 1.45 & 473.0 & 0.51 & 0.03 \\
\hline 29 & Water & 386.00 & 12.13 & 11.36 & 1.45 & 474.4 & 0.52 & 0.03 \\
\hline 30 & Water & 388.40 & 2.48 & 4.21 & 1.48 & 484.3 & 0.20 & 0.01 \\
\hline 31 & Water & 402.40 & 3.33 & 2.31 & 1.63 & 543.7 & 0.15 & 0.01 \\
\hline 32 & Water & 412.40 & 4.41 & 0.92 & 1.73 & 586.5 & 0.07 & 0.00 \\
\hline 33 & Water & 448.00 & 13.66 & 9.23 & 2.09 & 741.5 & 1.13 & 0.02 \\
\hline 34 & Water & 473.50 & 20.83 & 5.35 & 2.33 & 854.7 & 0.88 & 0.01 \\
\hline 35 & Water & 494.30 & 26.50 & 1.98 & 2.53 & 949.6 & 0.40 & 0.00 \\
\hline 36 & Cooling water & 295.00 & 2.05 & 1294.70 & 0.32 & 92.4 & 0.08 & 3.23 \\
\hline 37 & Water & 321.00 & 1.61 & 1294.70 & 0.68 & 206.2 & 4.58 & 3.23 \\
\hline 38 & Air & 580.20 & 1.02 & 140.20 & 5.70 & 301.4 & 53.39 & 0.00 \\
\hline 39 & MSW & 298.00 & 1.01 & 19.07 & 1.19 & - & 0.00 & 297.07 \\
\hline 40 & Combustion product & 1057.00 & - & 256.90 & 235.70 & 4109.0 & 199.70 & 21.62 \\
\hline 41 & Bottom ash & 1068.00 & - & 0.47 & - & - & 0.00 & 195.20 \\
\hline
\end{tabular}


Table 8. Main specifications of WTE (Waste-To-Energy) power plant

\begin{tabular}{lc}
\hline \multicolumn{1}{c}{ Name } & value \\
\hline The mass flow rate of MSW & $19.07 \mathrm{~kg} / \mathrm{s}$ \\
The mass flow rate of steam at the entrance of HPT & $90.2 \mathrm{~kg} / \mathrm{s}$ \\
The temperature of steam at the entrance of HPT & $713 \mathrm{~K}$ \\
The pressure of steam at the entrance of HPT & $130 \mathrm{~K}$ \\
Electrical power & $90 \mathrm{MW}$ \\
Air inlet temperature & $298 \mathrm{~K}$ \\
Stack flue gas temperature & $643 \mathrm{~K}$ \\
Pump isentropic efficiency & 0.8 \\
Turbine isentropic efficiency & 0.85 \\
LHV & $10 \mathrm{MJ} / \mathrm{kg}$ \\
\hline
\end{tabular}

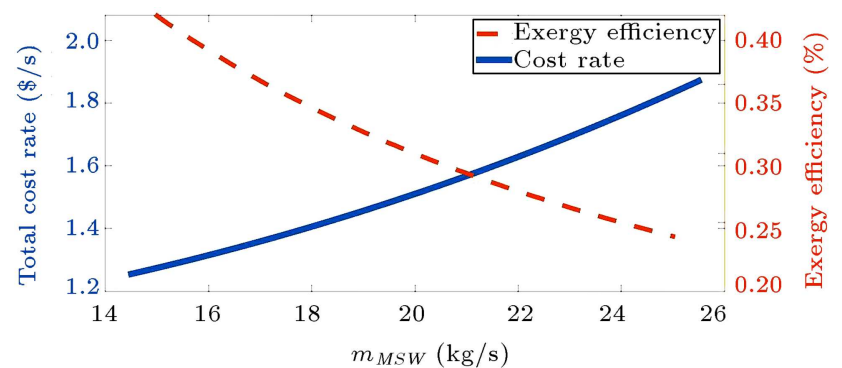

Figure 4. Effects of the changes in the rate of waste delivered to the incinerator on the objective functions.

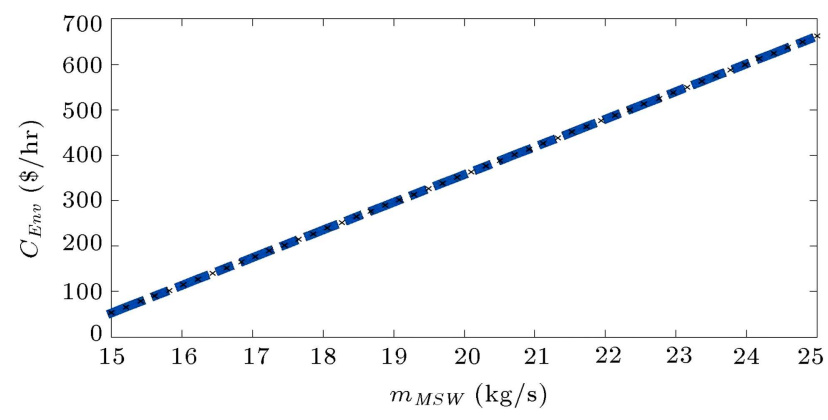

Figure 5. Environmental costs affected by the waste flow rate.

exergy efficiency and total cost rate have different reactions to MSW rate changes. This study evaluated the effect of variations in the waste flow rate inputted to the incinerator on the flue gas temperature released from the combustion chamber. The obtained results indicated that upon increasing the MSW flow rate, the temperature of the combustion chamber would increase as well. Changes in the rate of the penetrated MSW to the incinerator would increase the environmentaleconomic parameter. Due to an increase in the flue gas temperature as well as an increase in the temperature of the superheated vapor in the heat exchanger, the environmental cost rises exponentially (Figure 5).

Following an increase in the inlet pressure, the heat loss by the condenser is reduced. However, it

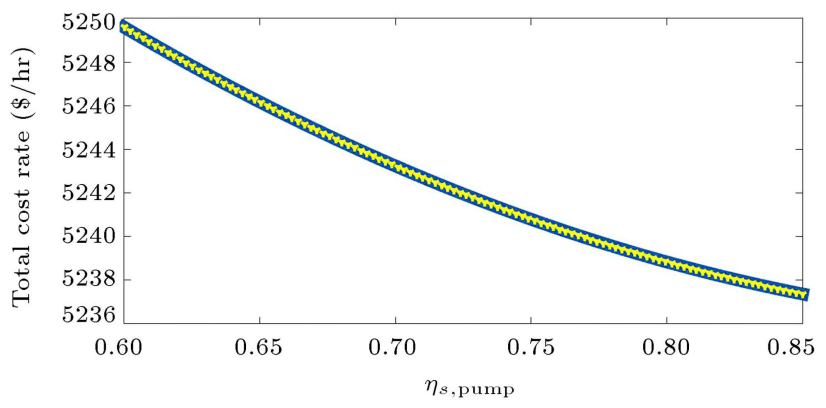

Figure 6. Effects of changes in the pump isentropic efficiency on the cost objective function.

increases the exergy destruction in a HPT. Such an increase results from the growth of the net output and the direct correlation between this parameter and the exergy efficiency. The rise in turbine input pressure would result in an increase in the total cost of the system. Based on this principle, with increasing pressure, if the temperature of the outlet stream is relatively high, it leads to an increase in turbine outcome work, which intensifies the net output by increasing the cost of equipping the turbine and ultimately the total system cost.

Since the isentropic efficiencies of the pump and turbine affect the system performance, changes in these parameters should be studied in the considered ranges. Increasing the isentropic efficiency of the turbine would increase the exergy efficiency of the cycle. With respect to the isentropic efficiency variations, the total cost can be affected, as shown in Figure 6. Evidently, upon increasing the isentropic efficiencies, the exergy efficiency of the system would increase. However, these variations reduce the total cost simultaneously, mainly due to the reduction of exergy destructions in the involved types of equipment. The turbine input temperature is one of the most important parameters in the thermodynamics design. Figure 7 illustrates the effect of changing the corresponding value while the other independent parameters are assumed to be 


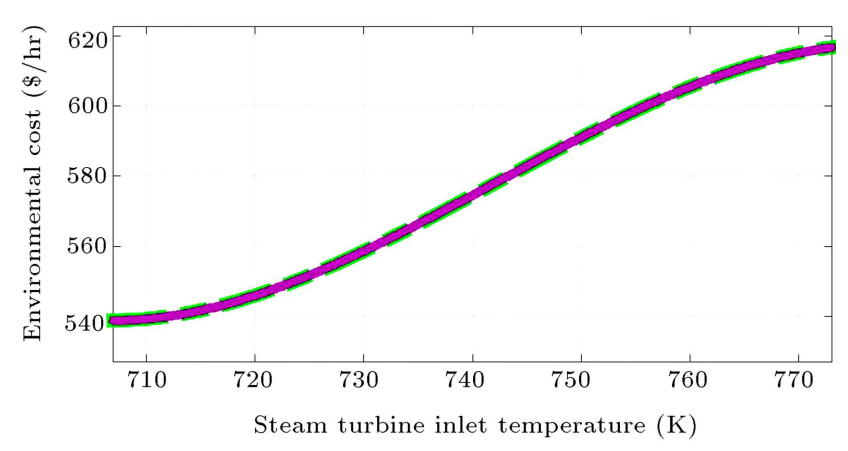

Figure 7. The environmental cost changes due to variations in turbine input temperature.

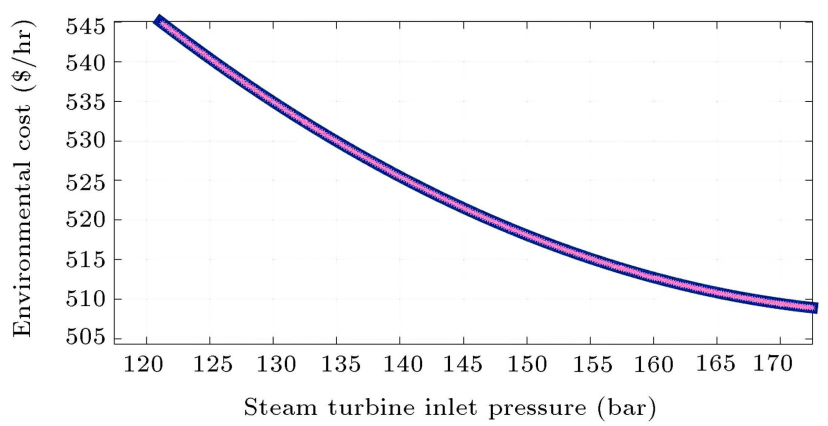

Figure 8. Effects of turbine input pressure changes on the environmental cost.

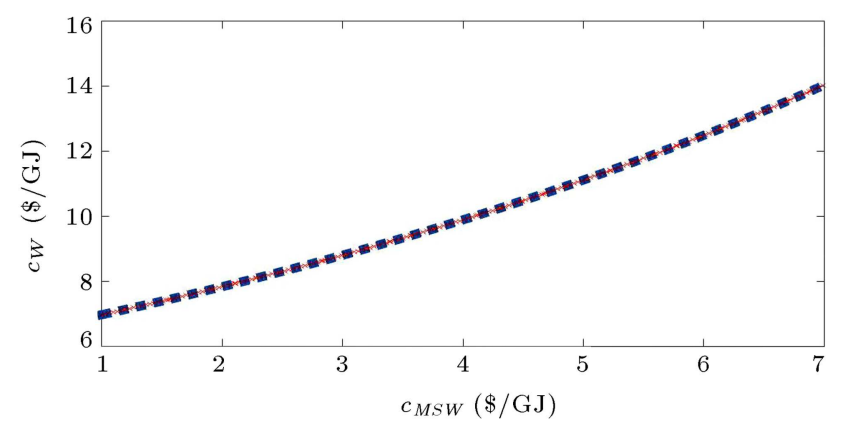

Figure 9. Effects of changes in the exergy unit cost of fuel on the exergy unit cost of output power.

constant. Upon increasing the inlet pressure up to the HPI, the cost of the environmental impact would consequently decrease, as depicted in Figure 8. These changes are in line with those obtained by Ahmadi et al. [53] and they are justifiable through the exergoenvironmental relations (Eq. (24)). Increasing the condenser pressure decreases the exergy efficiency of the cycle. The existing behavior complies with the results of the study conducted by Kaviri et al. [57]. In addition, increasing the condenser pressure up to 0.14 bar decreases exergy efficiency (30.94\%). Figure 9 shows the effect of changes in the exergy unit cost of fuel on the exergy unit cost of output power. It is conspicuous that growing the unit cost of fuel increases the unit cost of the produced power.

The exergy unit cost for providing MSW in the

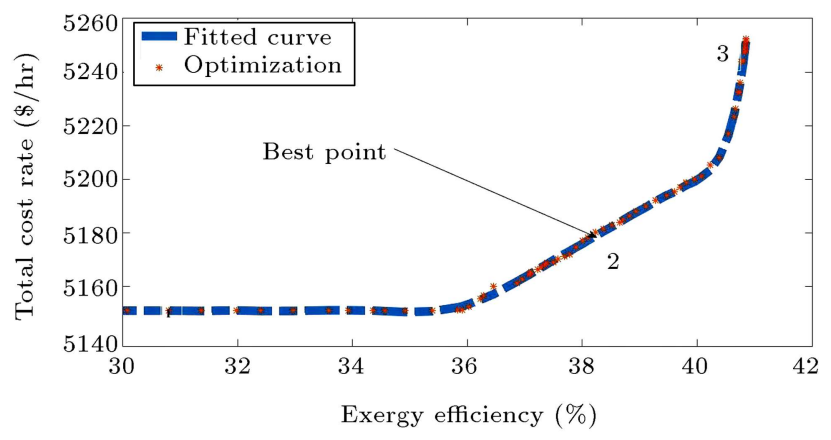

Figure 10. Pareto frontier for the total cost rate and exergy efficiency and the best fit for a relation to the objective functions.

plant is about 2 USD/GJ. Therefore, with a certain change in the cost of unit MSW, the direct effect on the cost of the exergy unit can be observed. The reason for such behavior is that the exergy unit cost of production has a direct relationship with the exergy unit cost of MSW, which is established by the exergoeconomic equations of steam and combustion products. The solid waste exergy unit cost is effective in the bottom ash exergy unit cost. As it is known, with the increase of this amount, the exergy unit cost of ash is affected and it would increase. To justify the behavior of the exergy unit cost of bottom ash as compared to the exergy unit cost of MSW, it is thought that by writing the exergoeconomic equations for the WIU, the increase in input values leads to an increase in the relative value of the output state. With increase in the inlet temperature of the pump, the net output power is reduced due to an increase in the temperature while keeping other parameters constant, thus increasing the enthalpy of the turbine output. By writing the balanced energy equation for the corresponding turbine, the result points to a reduction in the power output of the turbine [58].

In order to optimize the parameters related to the optimization method of the PSO algorithm, the maximum number of iterations, population (particles), inertia weight, individual learning factor, social (total) learning coefficient, and inertia adjustment ratio are $350,20,1,2,2$, and 0.99 , respectively. Figure 10 presents the application of these conditions to optimizing the cycle parameter, the graph of the exergy efficiency, and the total cost rate. Change in exergy efficiency varies from $30.1 \%$ to $40.8 \%$, and the range of changes in the total cost rate is around 100 USD per hour. It is important to note that in the multi-objective optimization and the Pareto method, each point can be the optimal point. Choosing the optimal solution is related to the priority and criterion of the decision variables based on the objective functions. The TOPSIS decision-making method is employed to determine the best point. Based on the definitions provided for 
the TOPSIS method, this process functions based on the ideal point (the highest efficiency with the lowest cost) and the worst point (the lowest efficiency with the highest cost). In this way, the target point must have the longest distance from the worst point and the smallest distance to the best point. Finally, it is calculated through the relation of the point with the maximum value of the TOPSIS method (Eq. (31)).

$$
\text { TOPSIS }=\frac{\Delta W}{\Delta W-\Delta B}
$$

where $\Delta W$ is the maximum distance between the worst point and the considered point and $\Delta B$ is the minimum distance of the best point to the point under consideration. By implementing the TOPSIS strategy to the Pareto frontier, the best point is demonstrated. Figure 11 shows the Pareto frontier with the best, worst, and determined points. It is obvious that the determined point (number 2) has the maximum distance from the worst point and minimum distance from the best point.

The results obtained from the optimization procedure revealed striking differences between preoptimization and after-optimization. In this case, by comparing exergy destructions among various components, the positive impacts of optimization on reducing negative parameters have been investigated. According to Figure 12, the cumulative exergy destruction results indicate a significant reduction in exergy destruction in each component. As is evident, a reduction in the quantity of exergy destruction for pumps is significantly

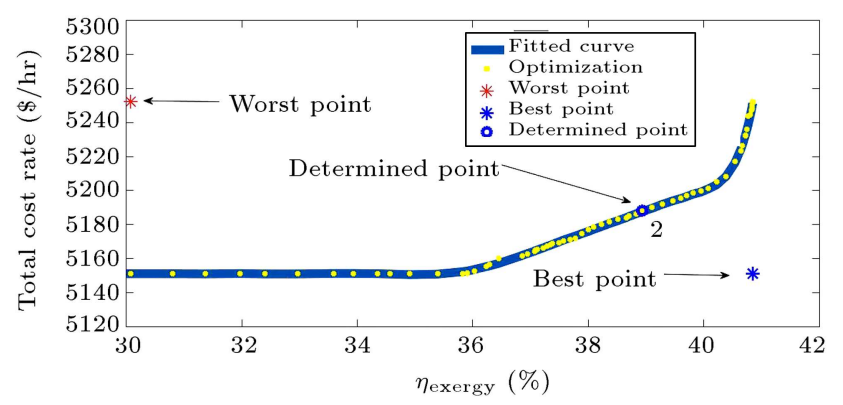

Figure 11. Pareto frontier with the declaration of the best point, the worst point, and the determined point.

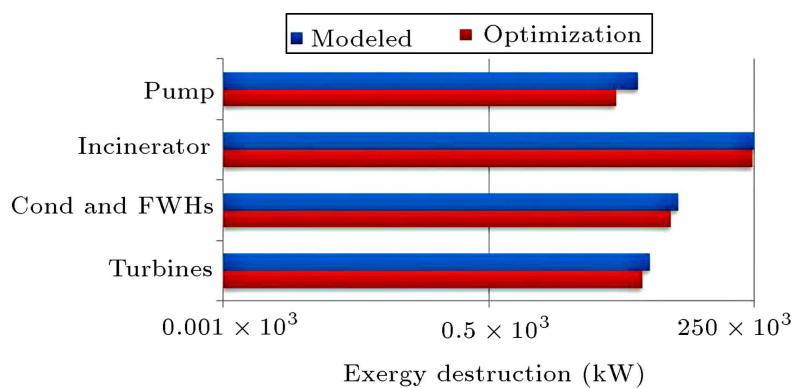

Figure 12. Comparison between optimized and simulated models in terms of exergy destruction. high and is remarkably similar to turbines' results. However, exergy destruction in the incinerator undergoes a slight fall due to the optimization process. By implementing the newly calculated design parameters in thermodynamics and exergy equations, system performance behaves optimally. Then, exergy efficiency of each component is computed and compared with the modeled values. Figure 13 demonstrates the values of the exergy efficiency of the cycle for each of the equipment and makes a comparison between pre- and post-optimization of the design parameters.

According to the provided figure, most of the components undergo a marginal increase in exergy efficiency. In this case, exergy efficiency values for HPT, IPT, LPT, SG (Steam Generator), incinerator, and deaerator raised from $88.77 \%, 92.29 \%, 67.04 \%$, $95.65 \%, 44.2 \%$, and $83.25 \%$ to $93.39 \%, 97.08 \%, 71.42 \%$, $97.35 \%, 47.73 \%$, and $85.79 \%$, respectively, while other components have the same behaviors, relatively.

\section{Conclusion}

The waste-to-energy power plants have significant impacts on human societies and these systems are characterized by ineffectiveness. Energy, exergy, economic and environmental analyses can be used to demonstrate these inefficiencies. Furthermore, the application of Multi-Objective Particle-Swarm Optimization (MOPSO) can define an optimum condition to improve the system operation. This study carried out exergoeconomic and exergoenvironmental analyses, as well as $3 \mathrm{E}$ optimization of the waste-to-energy power plant. Based on the findings, the main conclusions are achieved as follows:

- The exergy, exergoeconomic, and exergoenvironmental analyses were performed on the Amsterdam waste from the energy power plant. Due to the high irreversibility of the combustion process at high temperatures and heat transfer, results indicated a high share of exergy destruction for the waste incineration unit. Moreover, the waste incineration unit has the highest share of exergy destruction cost among all the existing components;

- Multiple-objective optimization with the help of particle swarm algorithm provided the optimum point for system performance. In this field, by considering the three objective functions and 14 decision variables, the optimization process was performed. In this study, MATLAB and EES software products were used to determine the best response for the system;

- The exergy destruction associated with each of the components was investigated. Optimization results pointed to the attenuation of the total exergy destruction. The alleviation of environmental impacts 


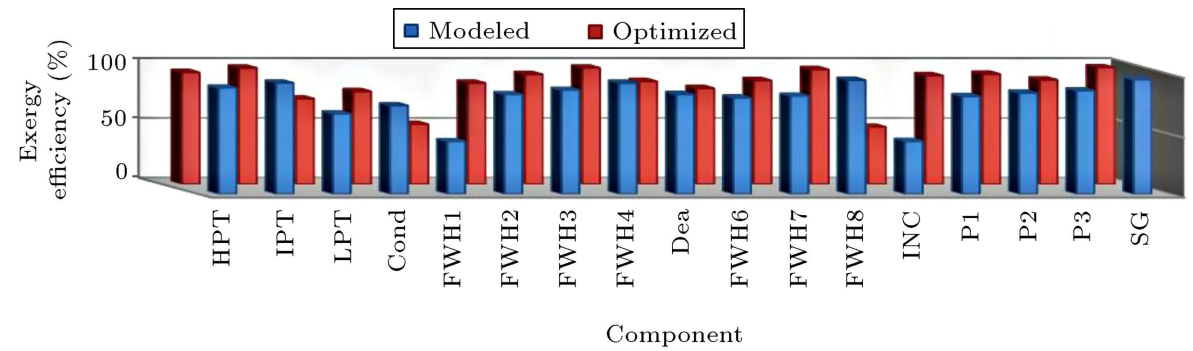

Figure 13. Values of the exergy efficiency of the cycle for each equipment and the comparison between pre- and post-optimizations of the design parameters.

can be achieved by reducing the waste flow rate in the furnace and consuming less fuel;

- By using the TOPSIS method, the best operational point for power plant concerning exergy efficiency and economic parameters was obtained. The determined point has specific properties that reduce exergy destruction and raise exergy efficiency in each component;

- The results of exergy analysis indicated that the incinerator unit had exergy destruction estimated at about $66 \%$ of the total. However, the pumps contributed the least in this term (around $1 \%$ of the total amount);

- The optimization results displayed that the exergy efficiency of the power plant was $38.931 \%$ and the total cost including the environmental costs was $5188.046 \mathrm{USD} / \mathrm{hr}$;

- Investigating the behaviors of design parameters in objective functions revealed a good insight into their effects on the optimization procedure. As presented earlier, increase in the feedstock rate and turbine inlet temperature would increase the environmental costs, accordingly;

- Upon making a comparison between the obtained results from the optimization procedure, the introduction of optimum working conditions increased exergy efficiency and reduced exergy destruction for components. The optimization results illustrated that the exergy efficiency of the power plant rose from $30.89 \%$ to $38.9 \%$.

\section{Nomenclature}

$C_{p} \quad$ Specific heat at constant pressure (kJ/kg.K)

$C_{D} \quad$ Cost of exergy destruction (USD $/ \mathrm{h}$ )

$c_{f} \quad$ Cost of fuel per unit of energy (USD/MJ)

ex $\quad$ Specific exergy $(\mathrm{kJ} / \mathrm{kg})$

$\dot{E} x \quad$ Exergy flow rate $(\mathrm{kW})$

$E x_{D} \quad$ Exergy destruction rate $(\mathrm{kW})$ $h$

$i$

LHV

Specific enthalpy $(\mathrm{J} / \mathrm{kg})$

$\mathrm{HHV}$

$\dot{m} \quad$ Mass flow rate $(\mathrm{kg} / \mathrm{s})$

$P \quad$ Pressure (bar)

PEC Purchase Equipment Cost (USD)

$Q \quad$ Heat $(\mathrm{kJ})$

$R \quad$ Gas constant $(\mathrm{kJ} / \mathrm{kg} \mathrm{K})$

$s \quad$ Specific entropy $(\mathrm{kJ} / \mathrm{kg} \mathrm{K})$

$T \quad$ Temperature $\left({ }^{\circ} \mathrm{C}\right.$ or $\left.\mathrm{K}\right)$

$\dot{W} \quad$ Work rate $(\mathrm{kW})$

$x \quad$ Molar fraction

$\dot{Z} \quad$ Capital cost rate (USD/h)

\section{Greek symbols}

$\mu$

$\eta$

$\xi$

$\phi$

$\psi$

$\beta$

Emission factor $(\mathrm{mg} / \mathrm{kWh})$

Efficiency

Chemical exergy/energy ratio

Maintenance factor

Exergy efficiency

Quality factor or exergy coefficient

\section{Subscripts and superscripts}

ch

Chemical

Cond

Condenser

$D$

Destruction

e Exit condition

F $\quad$ Fuel

fwh Feedwater heater

HPT High-Pressure Turbine

$i \quad$ Inlet condition

$k \quad$ Component

L Loss

ph Physical

Tot Total

$v \quad$ Velocity 


\section{References}

1. Branchini, L., Waste-to-Energy: Advanced Cycles and New Design Concepts for Efficient Power Plants, Springer (2015).

2. Behzadi, A., Gholamian, E., Houshfar, E., Ashjaee, M., and Habibollahzade, A. "Thermoeconomic analysis of a hybrid PVT solar system integrated with double effect absorption chiller for cooling/hydrogen production", Energy Equipment and Systems, 6(4), pp. 413-427 (2018).

3. Esmaeilion, F. "Hybrid renewable energy systems for desalination", Applied Water Science, 10(3), p. 84 (2020). DOI: $10.1007 / \mathrm{s} 13201-020-1168-5$

4. Buekens, A., Incineration Technologies, Springer (2013).

5. Esmaeilion, F., Ahmadi, A., Esmaeilion, A., and Ehyaei, M.A. "The performance analysis and monitoring of grid-connected photovoltaic power plant", Current Chinese Computer Science. 1, p. 1 (2020). DOI: https://doi.org/10.2174/2665997201999200511083228

6. Ahmadi, A. "Experimental study of a new flow conditioner on disturbed flow in orifice plate metering", Journal of Fluids Engineering, 131(5), pp. 1-131 (2009).

7. Esmaeilion, F., Waste to Energy Power Plants, Scholars' Press, pp. 1-46 (2019).

8. Chandler, A.J., Eighmy, T.T., Hjelmar, O., et al., Municipal Solid Waste Incinerator Residues, 67, Elsevier, pp. 1309-1310 (1997).

9. Ahmadi, A., Esmaeilion, F., Esmaeilion, A., Ehyaei, M.A., and Silveira, J.L. "Benefits and limitations of waste-to-energy conversion in Iran", Renewable Energy Research and Application (Aug. 2019). DOI: 10.22044/rera.2019.8666.1007

10. Bianchi, M., Branchini, L., De Pascale, A., Falchetti, M., and Fiore, P. "Advanced waste-to-energy steam cycles", Energy Procedia, 45(0), pp. 1205-1214 (2014).

11. Ehyaei, M.A., Ahmadi, A., and Rosen, M.A. "Energy, exergy, economic and advanced and extended exergy analyses of a wind turbine", Energy Conversion and Management, 183, pp. 369-381 (2019).

12. Ehyaei, M.A., Ahmadi, A., Assad, M.E.H., Hachicha, A.A., and Said, Z. "Energy, exergy and economic analyses for the selection of working fluid and metal oxide nanofluids in a parabolic trough collector", Solar Energy, 187, pp. 175-184 (2019).

13. Al-Sulaiman, F. "Thermodynamic modeling and thermoeconomic optimization of integrated trigeneration plants using organic Rankine cycles", Energy Conversion and Management, Elsevier BV, 69(12), pp. 209216 (2010).

14. Habibollahzade, A., Gholamian, E., Ahmadi, P., and Behzadi, A. "Multi-criteria optimization of an integrated energy system with thermoelectric generator, parabolic trough solar collector and electrolysis for hydrogen production", International Journal of Hydrogen Energy, 43(31), pp. 14140-14157 (2018).

15. Makkeh, S.A., Ahmadi, A., Esmaeilion, F., and Ehyaei, M.A. "Energy, exergy and exergoeconomic optimization of a cogeneration system integrated with parabolic trough collector-wind turbine with desalination", Journal of Cleaner Production, 273, pp. 123122123150 (2020) (JCLP_123122).

16. Ahmadi, A., Ehyaei, M.A., Jamali, D.H., Despotovic, M., Esmaeilion, A.F., and Hani, E.B. "Energy, exergy, and economic analyses of integration of heliostat solar receiver to gas and air bottom cycles", Journal of Cleaner Production, 273, pp. 123122-123148 (2020).

17. Gargari, S.G., Rahimi, M., and Ghaebi, H. "Energy, exergy, economic and environmental analysis and optimization of a novel biogas-based multigeneration system based on gas turbine-modular helium reactor cycle", Energy Conversion and Management, 185, pp. 816-835 (2019).

18. Alrobaian, A.A. "Improving waste incineration CHP plant efficiency by waste heat recovery for feedwater preheating process: energy, exergy, and economic (3E) analysis", Journal of the Brazilian Society of Mechanical Sciences and Engineering, 42(8), pp. 1-14 (2020).

19. Fujii, M., Dou, Y., Sun, L., et al. "Contribution to a low-carbon society from improving exergy of wasteto-energy system by upgrading utilization of waste", Resources, Conservation and Recycling, 149, pp. 586594 (2019).

20. Houshfar, E. "Thermodynamic analysis and multicriteria optimization of a waste-to-energy plant integrated with thermoelectric generator", Energy Conversion and Management, 205, p. 112207 (2020).

21. Carneiro, M.L.N.M. and Gomes, M.S.P. "Energy, exergy, environmental and economic analysis of hybrid waste-to-energy plants", Energy Conversion and Management, 179, pp. 397-417 (2019).

22. Zhang, Y., Ji, G., Ma, D., et al. "Exergy and energy analysis of pyrolysis of plastic wastes in rotary kiln with heat carrier", Process Safety and Environmental Protection, 142, pp. 203-211 (2020).

23. Yatsunthea, T. and Chaiyat, N. "A very small power plant-municipal waste of the organic rankine cycle and incinerator from medical and municipal wastes", Thermal Science and Engineering Progress, 18(3), p. 100555 (2020).

24. Chen, H., Zhang, M., Wu, Y., Xu, G., Liu, W., and Liu, T. "Design and performance evaluation of a new waste incineration power system integrated with 
a supercritical $\mathrm{CO}_{2}$ power cycle and a coal-fired power plant", Energy Conversion and Management, 210, p. 112715 (2020).

25. Ehyaei, M.A., Ahmadi, A., Assad, M.E.H., and Salameh, T. "Optimization of parabolic through collector (PTC) with multi objective swarm optimization (MOPSO) and energy, exergy and economic analyses", Journal of Cleaner Production, Elsevier BV, 234(4), pp. 285-296 (2019).

26. Shaygan, M., Ehyaei, M.A., Ahmadi, A., Assad, M.E.H., and Silveira, J.L. "Energy, exergy, advanced exergy and economic analyses of hybrid polymer electrolyte membrane (PEM) fuel cell and photovoltaic cells to produce hydrogen and electricity", Journal of Cleaner Production, 234, pp. 1082-1093 (2019).

27. Ehyaei, M.A., Ahmadi, A., Assad. M.E.H, and Rosen, M.A. "Investigation of an integrated system combining an organic rankine cycle and absorption chiller driven by geothermal energy: Energy, exergy, and economic analyses and optimization", Journal of Cleaner Production, Elsevier BV, 258(5), p. 120780 (2020).

28. Nabi, M.N., Rasul, M.G., Anwar, M., and Mullins, B.J. "Energy, exergy, performance, emission and combustion characteristics of diesel engine using new series of non-edible biodiesels", Renewable Energy, 140, pp. 647-657 (2019).

29. Ahmadi, A., Jamali, D.H., Ehyaei, M.A., and Assad, M.E.H. "Energy, exergy, economic and exergoenvironmental analyses of gas and air bottoming cycles for production of electricity and hydrogen with gas reformer", Journal of Cleaner Production, Elsevier BV, 259(6), 120915 (2020).

30. Shamoushaki, M., Ghanatir, F., Ehyaei, M.A., and Ahmadi, A. "Exergy and exergoeconomic analysis and multi-objective optimisation of gas turbine power plant by evolutionary algorithms", Case study: Aliabad Katoul Power Plant. International Journal of Exergy, 22(3), pp. 279-307 (2017).

31. Mondal, P. and Ghosh, S. "Externally fired biomass gasification-based combined cycle plant: exergoeconomic analysis", International Journal of Exergy, 20(4), pp. 496-516 (2016).

32. Jack, T.A. and Oko, C.O.C. "Exergy and exergoeconomic analysis of a municipal waste-to-energy steam reheat power plant for Port Harcourt city", International Journal of Ambient Energy, Informa UK Limited, 39(4), pp. 352-359 (2017). DOI: 10.1080/01430750.2017.1305447

33. Jurczyk, Ł. and Koc-Jurczyk, J. "Thermal conversion of municipal waste into energy: Prospects for the subcarpathia", Journal of Ecological Engineering, 18(2), pp. 157-165 (2017).

34. Fernández-gonzález, J.M., Grindlay, A.L., Serranobernardo, F., Rodríguez-rojas, M.I., and Zamorano, $\mathrm{M}$. "Economic and environmental review of wasteto-energy systems for municipal solid waste man- agement in medium and small municipalities", Elsevier BV, 67(4), pp. 360-374 (2017). DOI: 10.1016/j.wasman.2017.05.003

35. Kathirvale, S., Noor, M., Yunus, M., Sopian, K., and Halim, A. "Energy potential from municipal solid waste in Malaysia", 29, pp. 559-567 (2003). DOI: 10.1016/j.renene.2003.09.003

36. Song, J., Yang, W., Li, Z., Higano, Y., and Wang, X. "Discovering the energy, economic and environmental potentials of urban wastes: An input-output model for a metropolis case", Energy Conversion and Management, 114, pp. 168-179 (2016).

37. Rocco, M.V. and Colombo, E. "Exergy life cycle assessment of a waste-to-energy plant", Energy Procedia, 104, pp. 562-567 (2016). DOI: 10.1016/j.egypro. 2016.12 .095

38. Azami, S., Taheri, M., Pourali, O., and Torabi, F. "Energy and exergy analyses of a mass-fired boiler for a proposed waste-to-energy power plant in Tehran", Applied Thermal Engineering, 140, pp. 520-530 (2018). DOI: $10.1016 /$ j.applthermaleng.2018.05.045

39. Ofodu, J.C. and Abam, D.P.S. "Exergy analysis of Afam thermal power plant", NSE Technical Transactions, 37(3), pp. 14-28 (2002).

40. Esfandi, S., Baloochzadeh, S., Asayesh, M., et al. "Energy, exergy, economic, and exergoenvironmental analyses of a novel hybrid system to produce electricity, cooling, and syngas", Energies, 13(23), p. 6453 (2020).

41. Derakhshandeh, P., Ahmadi, A., and Dashti, R. "Simulation and technical-economic-environmental optimization of the General Electric GE90 hydrogen turbofan engine", International Journal of Hydrogen Energy, Elsevier BV, 46(5), pp. 3303-3318 (2020).

42. Ehyaei, M.A., Baloochzadeh, S., Ahmadi, A., and Abanades, S. "Energy, exergy, economic, exergoenvironmental, and environmental analyses of a multigeneration system to produce electricity, cooling, potable water, hydrogen and sodium-hypochlorite", Desalination, Elsevier BV, 501(7), p. 114902 (2020).

43. Bejan, A. and Tsatsaronis, G., Thermal Design and Optimization, John Wiley \& Sons (1996).

44. Tammemagi, H.Y., The Waste Crisis: Landfills, Incinerators, and the Search for a Sustainable Future, Oxford University Press (1999).

45. Song, G., Shen, L., and Xiao, J. "Estimating specific chemical exergy of biomass from basic analysis data", Industrial \& Engineering Chemistry Research, 50(16), pp. 9758-9766 (2011).

46. Cooper, C.D., Kim, B., and MacDonald, J. "Estimating the lower heating values of hazardous and solid wastes", Journal of the Air \& Waste Management Association, 49(4), pp. 471-476 (1999).

47. Meraz, L., Oropeza, M., and Dominguez, A. "Prediction of the combustion enthalpy of municipal solid waste", Chem Educator, 7(02), pp. 66-70 (2002). 
http:// www.springerlink.com/content

/u5101w24k5676078/ fulltext.pdf (9. Nov 2010).

48. Hepbasli, A. "A key review on exergetic analysis and assessment of renewable energy resources for a sustainable future", Renewable and Sustainable Energy Reviews, 12(3), pp. 593-661 (2008). DOI: 10.1016/j.rser.2006.10.001

49. Bejan, A., Tsatsaronis, G., and Moran, M.J., Thermal Design and Optimization, John Wiley \& Sons (1995).

50. Mignard, D. "Correlating the chemical engineering plant cost index with macro-economic indicators", Chemical Engineering Research and Design, 92(2), pp. 285-294 (2014).

51. Dincer, I., Rosen, M.A., and Ahmadi, P., Optimization of Energy Systems, John Wiley \& Sons (2017).

52. Penman, J. et al. "Good practice guidance and uncertainty management in national greenhouse gas inventories", IPCC National Greenhouse Gas Inventories Programme, 12(6), pp. 1-287 (2001).

53. Ahmadi, P., Dincer, I., and Rosen, M.A. "Exergy, exergoeconomic and environmental analyses and evolutionary algorithm based multi-objective optimization of combined cycle power plants", Energy, 36(10), pp. 5886-5898 (2011).

54. Rao, S.S. and Rao, S., Engineering Optimization: Theory and Practice, John Wiley \& Sons, Inc., New Age International Ltd., pp. 1-435 (2009).

55. Murer, M.J., et al. "High efficient waste-to-energy in Amsterdam: Getting ready for the next steps", Waste Manag. Res., 29(10), SUPPL., pp. 20-29 (2011).

56. Tabasová, A., Kropáč, J., Kermes, V., Nemet, A., and Stehlík, P. "Waste-to-energy technologies: Impact on environment", Energy, 44(1), pp. 146-155 (2012). DOI: $10.1016 /$ j.energy.2012.01.014

57. Kaviri, A.G., Jaafar, M.N.M., and Lazim, T.M. "Modeling and multi-objective exergy based optimization of a combined cycle power plant using a genetic algorithm", Energy Conversion and Management, 58, pp. 94-103 (2012).

58. Ahmadi, P. "Modeling, analysis and optimization of integrated energy systems for multigeneration purposes", (2013).

\section{Biographies}

Farbod Esmaeilion received his BSc and MSc degrees from the ArakUT and IUST, respectively. He has satisfactory experience in Mechanical Engineering and Energy with a passion and expertise in thermodynamics, renewable energies, HVAC, CCHP, and desalination.

Abolfazl Ahmadi has been an academic staff member at the Department of Energy Systems Engineering (School of Advanced Technologies (New Technologies), Iran University of Science and Technology) since 1992. He also obtained his $\mathrm{PhD}$ in Mechanical Engineering from Sheffield University in the UK. His research interests include energy systems optimization.

Reza Dashti is an academic staff member at the Department of Energy Systems Engineering (School of Advanced Technologies (New Technologies), Iran University of Science and Technology). His research interests include energy economics and electrical engineering. 